\title{
Antroposentriese prediking
}

Met behulp van de algemene hermeneutiek, de communicatieleer, de taalwetenschap en de moderne retoriek probeert de huidige homiletiek tot en zelfstandige weterschap binnen het terrein van de (praktische) theologie te worden - G D J. Dingemans

\section{L.F. Schulze}

Departement Dogmatologie en Ekklesiologie

Potchefstroomse Universiteit vir $\mathrm{CHO}$

POTCHEFSTROOM

\begin{abstract}
The shift of attention from the Bible text to the recipient in modern homiletics is i.a. due to the deep influence of some 'auxiliary sciences' on homiletics, especially linguistics, with its reception theory. The effect of this paradigm shift is illustrated by means of some examples from modern sermons and sermon-sketches. The incisive character of the paradigm shift becomes apparent when set against the background of text-oriented homiletics of traditional reformed theology. Finally, some dogmatic and confessional pitfalls of modern homiletics are briefly mentioned.
\end{abstract}

\section{Inleiding}

Greidanus (1989:159-166) bespreek vier foutiewe verklaringsmetodes om die Bybelteks in die prediking na die leefwêreld van die huidige hoorders oor te bring:

* Allegorisering, wat onder of agter die teks na die ware betekenis daarvan soek (kyk ook Strydom, 1989:14).

* Spiritualisering, wat die konkrete aardse en historiese werklikheid waarvan die teks praat, ignoreer en dit vervlugtig tot 'n geestelike analogie wat op vandag se hoorders toegepas kan word.

* Nabootsing, wat Bybelse figure waarvan die teks praat tot voorbeelde of modelle verhef wat nageboots moet word of nie nageboots moet word nie (ook bekend as eksemplarisme - Greidanus, 1970:9-11; Strydom, 1989:2, 64-83).

* Nou verwant aan nabootsing of eksemplarisme is moralisering, wat "the description of past people into prescription for people today" transformeer (Greidanus, 1989:165; vgl. ook Kromminga, 1983:38). 
$\mathrm{Al}$ vier metodes is vorme van antroposentriese Skrifverklaring, wat lei tot antroposentriese prediking. Hierdie tipe prediking ontkrag die Bybel en staan lynreg teenoor die gereformeerde Christosentriese prediking (Greidanus, 1989:116-118).

Dit is duidelik dat bogenoemde fyn onderskeidings van Greidanus onderling eng verweef is. Sy onderskeidings word hier egter nie op die voet gevolg nie maar meer omvattend getipeer as 'n gebruik van die Skrif in oneintlike of oordragtelike $\sin$ (Schäfer, 1993:96) ten behoewe van die sielkundige behoeftes of sosio-politieke ideale van die hoorders.

Hierdie artikel belig hoofsaaklik die verskuiwing in lewensbeskoulike vertrekpunte wat aan die antroposentriese prediking soos voorgestaan deur die moderne homiletiek ten grondslag lê. Eerstens word aangetoon dat die hulpwetenskappe wat die homiletiek gebruik, in die antroposentriese prediking ' $n$ rol speel. Tweedens word die praktiese vrug van die homiletiek by wyse van voorbeelde bespreek - voorbeelde wat 'n tendens in die moderne geestesklimaat aandui en vermenigvuldig kan word (kyk Greidanus, 1970:11-16), maar nie pretendeer om tiperend van die huidige Protestantse prediking te wees nie. Derdens word die omvang van die sogenaamde paradigmaverskuiwing in die modeme homiletiek afgeëts teen die agtergrond van die gangbare gereformeerde teks-georiënteerde homiletiek. Ten slotte word enkele slaggate aangedui waarin die moderne homiletiek die gereformeerde prediking kan laat beland.

\section{Hoe behoort vandag se predikant te preek?}

\subsection{Homiletiek as wegwyser}

Die antwoord op bogenoemde vraag word verskaf deur die teologiese wetenskap wat as preekkunde of homiletiek bekend is. Met behulp van hierdie wetenskap word die predikant geleer hoe om te preek. Sy manier van preek gaan dus bepaal word deur dit wat hy in die homiletiek leer. Maar wat hy in die homiletiek leer, word op sy beurt bepaal deur die uitgangspunt, metode en riglyne wat hierdie vak aan hom bied. Die uitgangspunt, metode en riglyne van die homiletiek word op sy beurt weer bepaal deur die vraag hoe diep die homiletiek gaan drink uit die fontein van die vakwetenskappe wat te hulp geroep word. Daar kan waarheidselemente van die hulpwetenskappe oorgeneem word en in die eie teologiese vertrekpunte en metode ingebou word - die ensiklopedie (opvoedingsirkel) van die wetenskappe vorm immers ' $n$ eenheid omdat God Hom in sy werke en sy Woord geopenbaar het. Die homiletiek kan egter ook dieper uit die fontein van die vakwetenskappe drink, naamlik deur waarheidsmomente én vertrekpunte én teorieë van die hulpwetenskappe oor te neem. 


\subsection{Die moderne homiletiek se hulpwetenskappe}

Die woorde van Dingemans (1992:131), wat aan die begin van die artikel as motto oorgeneem is, toon duidelik aan watter vakwetenskappe die homiletiek te hulp roep om sy eie plek binne die terrein van die sogenaamde praktiese teologie te verseker.

Eerstens word die algemene hermeneutiek genoem. 'n Mens sou verwag dat die homiletiek as teologiese wetenskap by die teologiese hermeneutiek (tradisioneel gesien as die teorie van Bybelse uitlegkunde) sekere beginsels en insigte sou oorneem. ' $n$ Preek is tog immers gegrond op eksegese met sy hermeneutiese onderbou. Dit is egter nie die geval nie, want die moderne homiletiek stel volgens Dingemans sy visier wyer en put uit die algemene hermeneutiek. Die algemene hermeneutiek is ' $n$ belangrike faset van die moderne taalwetenskap. Nethersole (1982:147) skets die agtergrond van die belangstelling in literêre hermeneutiek soos volg:

The present revival of interest in the phenomenon of understanding as a precondition for the interpretation of texts, is mainly due to the work of Heidegger, Gadamer and Habermas. None of these theorists is a literary critic, yet their thinking has profoundly influenced the theory of literature ... The influence of general hermeneutics upon literary scholars is, indeed, incalculable if one considers the epoch-making work of Wilhelm Dilthey (18331911): The Rise of Hermeneutics (1900), as well as the long tradition of classical hermeneutics... However, there is undoubtedly much truth in the widely held belief that hermeneutics gains in interest and emphasis at times of crisis, or to be more exact, at those moments in history when established world-views flounder and the intellect finds it necessary either to legitimise inherited traditions - as is the case with Gadamer - or to radically criticise them, as Habermas does.

Die tweede hulpwetenskap wat Dingemans noem, is die kommunikasieleer. Hierdie wetenskap beslaan ' $n$ wye gebied en omvat verskeie vakwetenskappe, want die studie van kommunikasieprosesse "lê ' $n$ verbinding tussen die sosiale wetenskappe enersyds en die taalwetenskap en inligtingstegniek andersyds" (Anon., 1974:178). Dit is 'n onbegonne taak om die inter-wetenskaplike karakter van kommunikasie hier te probeer ontrafel omdat dit ons in die teoriee van die sosiologie en die literaturwetenskap sal verstrik en op 'n syspoor sal laat beland. Daarom word volstaan met die opmerking dat die modeme homiletiek sterk aanleun teen die kommunikasieleer van Habermas (vgl. Pieterse, ongepubliseer, 7178), wat sterk op die samelewing gerig is (vgl. Bernstein, 1983:228) en verweef is met sy neo-Marxistiese maatskappykritiek (McCarthy, 1982:57). Hoevéél die modeme teologiese homiletiek van die kommunikasieproses van die neo-Manxisme oomeem, is ' $n$ terrein wat ' $n$ aparte studie nodig maak 
Die derde hulpwetenskap wat Dingemans noem, is die taalwetenskap. Die verbinding van die algemene hermeneutiek en die kommunikasieleer met die taalwetenskap (en sosiologie) is reeds hierbo aangetoon. Die taalwetenskap kom later weer aan die orde.

Die laaste hulpwetenskap wat Dingemans noem, is die retoriek (die oorredingskuns), wat deur die Grieke reeds hoog aangeslaan is, later in onbruik geraak het en tans weer herleef (vgl. teoloë van US se werkgroep vir retoriek).

Oorsien mens die opsomming van Dingemans, is dit duidelik dat die moderne homiletiek hoofsaaklik uit die literatuurwetenskap en die sosiologie put.

\section{3 'n Trojaanse perd?}

Die vraag is nou: hoe diep put die homiletiek uit hierdie hulpwetenskappe? Hierbo is aangetoon dat die antwoord op hierdie vraag in vele opsigte nog braak lê. Dingemans (1992:124) lig egter die sluier oor een aspek van hierdie vraag, naamlik die invloed van die taalwetenskap op die homiletiek as hy skryf:

De meest fundamentele ontwikkeling die binnen de homiletiek heeft plaats gevonden, duid ik aan als de verschuiving van de aandacht van de bijbeltekst naar de hoorder. In de Amerikaanse literatuur spreekt men zelfs van een 'paradigm shift'.

Dat hierdie paradigmaverskuiwing in die homiletiek deur die invloed van die taalwetenskap voltrek is, toon Dingemans duidelik aan. Hy haal immers Sulciman aan (Dingemans, 1992.126), wat die aksentverskuiwing van uitleg na ontvangs (resp. van teks na hoorder) tipeer as 'n "quiet revolution" in die literatuurwetenskap. Hierdie geruislose rewolusie het reeds sy neerslag in die moderne hermeneutiek gekry en verskyn tans ook in die homiletiek.

As voorbeelde van bogenoemde paradigmaverskuiwing bespreek Dingemans (1992:124-126) vervolgens kortliks die opvattings van Ernst Lange, Fred Craddock en van laasgenoemde se leerling Thomas Long, ' $n$ boeiende redenaar

Long byvoorbeeld sluit aan by die Franse strukturalis, Greimas, met sy analise van verhalende tekste (kyk Cloete et al., 1985:46-47,67) en is 'n voorstander van narratiewe prediking (Pieterse, 1985:223-229, 1987:164, 179-184). Narratiewe prediking "uses historical facts, or authentic experiences and events, to tell something beyond the mere facts or experiences. It presents real-life experience in a different guise so as to make it intelligible ..." (Pieterse, 1987:166 - my kursivering). 'n Kenmerkende wyse waarop 'n verhaal met hoorders kommunikeer, is "deur die identifikasie van die hoorder met 'n karakter(s) in die verhaal" (Pieterse, $1985: 223 ; 1987: 179)$. Narratiewe prediking lei gevolglik tot allegorie en nabootsing (vgl. Greidanus se onderskeidings). 
Dit is opmerklik dat die genoemde paradigmaverskuiwing in die homiletiek nie op grond van interne teologiese oorwegings plaasgevind het nie. Anders gestel: homiletici het nie op grond van Skrifgetuienis tot die besef gekom dat die tradisionele aksent op die teks of perikoop verkeerd is nie. Inteendeel, die tradisionele aksent op die teks, gangbaar sedert die Reformasie, is in die Protestantse teologie nog tot aan die begin van die jare sewentig beklemtoon. Daarvan getuig onder andere Wolfgang Trilhaas se Evangelische Predigtlehre (1948), K. Dijk se De dienst der prediking (1955), Karl Barth se Homiletik (1966) en Rudolf Bohren se Predigtlehre (1974). Gedurende die sewentigerjare word die paradigmaverskuiwing voltrek. Die rede vir die paradigmaverskuiwing is nie ver te soek nie. In 1970 verskyn daar naamlik 'n nuwe literatuurteorie op die horison: die resepsie-estetika of resepsieteorie soos geformuleer deur Wolfgang Iser in sy Die Appelstruktur der Texte (1970) en H.R. Jauss se Literaturgeschichte als Provokation (1970). Daarmee is die aksent van die teks na die hoorder of leser verlê.

Dingemans (1992:126-127) teken die verloop van die taalteoretiese, hermeneutiese en homiletiese ontwikkeling soos volg: -

Vóór 1970 ging het uitsluitend in de literatuurwetenschap, maar ook in de homiletiek, over teksten en schrijvers en over preken en predikers, nu komen eindelijk ook de lezers en hoorders volop in de belangstelling te staan. De receptietheorieën van Wolfgang Iser en Hans Jauss hebben algemeen de aandacht getrokken; de hermeneutische aanpak van Gadamer en Ricoeur heeft de plaats van de lezer en hoorder bij de interpretatie van de werkelijkheid in het algemeen en van teksten in het bijzonder ontdekt.

Dingemans (1992:127) toon ook aan wat die paradigmaverskuiwing van teks na hoorders inhou, naamlik 'n relativering van die boodskap van die teks: die betekenis van die teks of perikoop is die betekenis wat die hoorder (leser) in sy bepaalde situasie daaraan heg:

De boodschap van de tekst is niet 'objectief en 'eens en voor altijd' vast te stellen. Het gaat altijd om datgene wat de hoorder of lezer er in een bepaalde situatie in hoort of leest. Er is sprake van een hermeneutische cirkel. De hoorder doorloopt de cirkelgang tussen tekst en eigen interpretatie en probeert zo tot een eigen verstaan te komen. En dat verstaan moet natuurlijk in een verificatieproces worden gecontroleerd en geverifieerd. De exegese als interpretatie van teksten houdt daarom steeds meer rekening met de oorspronkelijke en de hedendaagse hoorders.

Ons het in die resepsieteorie inderdaad met ' $n$ 'stil rewolusie' en met 'n paradigmaverskuiwing (verskuiwing van vertrekpunte) te doen. Dat die modeme hermeneutiek en homiletiek juis by die resepsieteorie gaan kers opsteek het, bring vir die teologie ernstige gevolge mee. Die Woord van God is immers nou nie meer die gesagvolle en geldende Woord nie, maar sy waarheid en betekenis hang af van dit wat die hoorder of leser daaraan heg (vgl. Cloete et al., 1985:50: resepsie 
is "die ontvangs, reproduksie, aanpassing, assimilasie of kritiese beoordeling ..."). Die historiese feit dat Christus as offerlam plaasbekledend in die plek van sondaars gely het, word afgeskaal tot die subjektiewe betekenis wat die hoorders in hulle omstandighede daaraan heg. Voeg daarby dat die eksegese nie meer die objektiewe teks ("daar staan geskrywe") vir die hoorders moet verklaar nie, maar dat die eksegese die teks moet verklaar in terme van wat die hoorders in verlede en hede daarvan verstaan. Die gevolg van hierdie hermeneutiek is dat die homiletiek nie meer teksgerig is nie maar gemeentegerig is. So word die ewige, objektiewe waarheid ("eens en vir altyd") van God se Woord verlaag tot 'n subjektiewe belewing van wat die Woord sê.

Wat die paradigmaverskuiwing in die homiletiek inhou, word vervolgens aan die hand van voorbeelde verduidelik.

\section{Hoe preek vandag se predikant?}

Die voorbeelde wat behandel gaan word, hou nie in dat alle predikante vandag preek soos in die voorbeelde uiteengesit nie. Dit toon slegs aan dat dic teorie van die homiletiek in die praktyk van die prediking tog 'n sekere neerslag vind.

Die voorbeelde word geneem uit (meesal) resente Duitse en Afrikaanse preeksketse en preekbundels. Ouer voorbeelde toon dat die oordragtelike gebruik van die Skrif niks nuuts is nie - dit kom trouens reeds by Origenes (185-254) voor (kyk Routley, 1950:224) en ontvang bloot wetenskaplike sanksie in die moderne homiletiek. Oor die Duitse literatuur word eers die volgende verduidelik:

Schäfer het in 'n onlangse artikel onder andere vier gedrukte homiletiese sketse met die oog op die Goeie Vrydagdiens van 1991 betrek om die vraag te beantwoord in hoeverre Luther se 'teologie van die kruis' nog in die moderne prediking ter sprake kom (kyk Schäfer, 1993:92-96). As daar 'n erediens is waarin die tema van skuld en versoening, van plaasbekledende lyding en regverdigmaking ter sprake kom, is dit ooglopend die diens op Goeie Vrydag. Uit die gepubliseerde homiletiese sketse, wat deur baie predikante vir die voorbereiding van hulle preke gebruik word, neem Schäfer telkens een voorbeeld. Die perikoop wat gelees moet word en waaruit gepreek moet word, is in die Agenda van die Lutherse Kerk voorgeskryf: Johannes 19:16-30.

Al die voorbeelde word terwille van oorsigtelikheid in twee kategoriee verdeel, terwyl die eerste groep weer onderverdeel word. Vanselfsprekend is daar oorvleueling. Daarom kan die twee kategorieë beskou word as twee aksente, of, as u wil, twee metodes van Skrifhantering binne die homiletiese proses van hoordergerigtheid. Omdat die aandag van die Bybelteks na die hoorders verskuif het, merk ' $n$ mens by predikers ' $n$ groot mate van vryheid in die aanwending van die teks om by die hoorders uit te kom. Die vrye aanwending van die teks hou in dat 
dit soms in oordragtelike sin aangewend word, en andersins dat dit geherinterpreteer word.

\subsection{Skrifgebruik in oordragtelike sin}

Om 'n teks of perikoop in oordragtelike sin te gebruik beteken dat die betrokke teks of perikoop uit sy kultuurhistoriese en openbaringshistoriese verband uitgelig word en van sy letterlike betekenis gestroop word om as simbool of voorbeeld te dien wat op die hoorders appelleer. Hierdie Skrifhantering, bekend as allegoriese eksegese, het eerstens ten doel om die sielkundige behoeftes van die hoorders te bevredig deur hulle te vertroos, te bemoedig en/of bepaalde gesindhede by hulle te stimuleer. Tweedens kan die allegoriese eksegese aangewend word om die sosio-politieke situasie van die hoorders te probeer bevestig (handhawing van die status quo) of om hulle sosio-politieke nood aan te dui en hulle aspirasies te stimuleer (revolusieteologie).

\subsubsection{Vir psigologiese doeleindes}

In die Calwer Predigthilfen (1990:196-202 - verdere bibliografiese besonderhede in Schäfer, 1993:92, verw. 4) bied G. Krusche drie moontlike preeksketse van Johannes 19:16-30 aan, waarin eksegese en meditasie tot vrug kom. Die eerste twee sketse van Krusche is vir ons onder bogenoemde opskrif van belang.

\subsubsection{Voorbeeld 1}

Die eerste skets is ' $n$ voorbeeld van ' $n$ 'nadenkende preek'. Hier word die kruis 'met die oè van die geloof betrag en is dit ' $n$ 'teken van solidariteit', ' $n$ 'daad van gehoorsaamheid' en ' $n$ 'teken van bevryding'. In elke geval staan Jesus aan ons sy en help Hy ons om ons eie leed met waardigheid, gehoorsaamheid en in deelname aan sy oorwinning te dra.

\subsubsection{Voorbecld 2}

Krusche se tweede skets is ' $n$ leidraad vir predikante om uit Johannes 19:16-30 'vertroostende prediking' na vore te bring. Die kerngedagte wat in sodanige vertroostende prediking moet figureer, is die volgende: Jesus het vir ons die pad na die lewe geopen en ons verlos "van presteerdruk en die dwang om onsself te regverdig'. Soos blyk uit Jesus se woorde aan sy moeder en aan Johannes ("Vrou, dáár is u seun ... Dáár is jou moedeı" - vs. 26-27) het Hy ons "tor liefde en oorgawe' bevry (kyk Schăfer, 1993:92).

'n Kanttekening is hier van pas. Vir 'n gemeente wat in die Westerse tegnokratiese samelewing met sy kompetisie en verhoogde produktiwiteit vasgevang sit, is verlossing uit presteerdruk en selfregverdiging inderdaad 'n oorgang na ruimtes 
waarin daar weer asemgehaal kan word. Of hierdie sielkundige 'verlossing' in die konteks van 'n tegnokratiese samelewing werklikheidsgetrou is, bly 'n ope vraag.

\subsubsection{Voorbeeld 3}

'n Preek uit 'n preekbundel van 'n Afrikaanse predikant het Genesis 13:11, 12 en Genesis 19:16, 17, 26 as teksverse. Die hoofgedagte is: Die verkeerde keuse van Lot. Ook hier word die Bybeltekste in oordragtelike sin gebruik om op die houding en gesindheid van die hoorders te appelleer. Die inhoud van die preek word vervolgens weergegee deur gebruik te maak van die sporadiese opsommings en enkele aanhalings uit die preek met publikasiedatum en bladsynommers tussen hakies.

Lot se keuse was verkeerd, want in die Jordaanstreek het die goddelose Sodom en Gomorra gelê. Lot se verkeerde keuse sou nie so dodelik gewees het, as hy (soos Abraham) "bereid was om in tente te bly woon nie" (1990:10). Dit het hy wel aanvanklik gedoen totdat hy sy tente by Sodom opgeslaan het (Gen. 13:12), "maar in Genesis 19 vind ons hom in die poort van Sodom?". Die verklaring hiervoor is:

Waarskynlik het die dogters hulle morsdood geskaam vir die ou primitiewe tent toe die kêrels van Sodom kom kuier het. Waarskynlik het Lot se vrou 'n spoghuis in 'n spogwoonbuurt in Sodom begeer. En toe het Lot maar in Sodom gaan bly ... Lot het nie meer die moed gehad om die skatte van Sodom prys te gee nie. Daarom is hy verantwoordelik vir die vreeslike gevolge wat sy verkeerde keuse meegebring het (1990:10).

Die gevolg van sy verkeerde keuse was dat "die sonde in Sodom ... vir Lot doodongelukkig gemaak" het. Omdat die mense van Sodom hom verwyt het dat hy oor hulle wil baasspeel (Gen. 19:9), "wil ons aanneem dat Lot teen die sonde getuig het ... Tog lyk dit asof sy geloof in Sodom baie skade gely het". Hierdie aanname word gemaak op grond daarvan dat Lot getalm het toe die engele hom aangejaag het. Hy was nie baie haastig nie "omdat hy al sy besittings ... aan die verwoesting moet prysgee en omdat hy voortaan 'n brandarm man sal wees" (1990:11).

Die toepassing wat uit bogenoemde volg, is dat Lot vir ons 'n ernstige waarskuwing is

... om nie in die poorte van Sodom te gaan bly nie. Die poorte van Sodom: dit kan slegte maats wees, ' $n$ ongeoorloofde liefdesverhouding, die dobbelsale in ons land - ag, jy sal weet wat dit is. As jy op hierdie oomblik daar bly, vlug betyds weg - voordat jou geloof soveel skade opgedoen het dat jy nie wil padgee nie (1990:11). 
Om uit die donker ellende van Lot as voorbeeld te kom word Lot se sielsgesteldheid gerekonstrueer en vorm dit die grond vir 'n kondisionele regverdigmaking: Die hoorders word gevra wat na hulle mening in die hart van Lot ongegaan het toe hy die soutpilaar gesien het en uitgevind het wat sy dogters gedoen het. Die antwoord:

Sekerlik die diepste selfverwyt: dis alles my skuld! Sekerlik die diepste skaamte voor God: hoe het ek nie u Naam oneer aangedoen nie! Sekerlik die diepste skuldbelydenis: o God, wees my, sondaar, genadig! (1990:13).

Die laaste sin lei die prediker tot die ligpunt in hierdie treurige geskiedenis:

U vra: kan daar vir ' $n$ man soos Lot genade wees? En dan kom die antwoord: ja, duisendmaal JA! God het nie behae in die dood van die sondaar nie (Eseg 18:32). In vers 29 staan duidelik dat God, ter wille van die voorbidding van Abraham, vir Lot gered het ...

By Jesus Christus is daar genade vir elkẹ Lot, vir elke huisgesin soos dié van Lot, wat in ware berou by Hom gaan skuil; wat in ware bekering met Sodom breek en soos pelgrimsreisigers in die tente van Abraham gaan bly (1990:13)

Oor dié preek moct ook 'n paar opmerkings gemaak word.

Ons het hier inderdaad ' $n$ preek oor Lot. Met behulp van psigologiese eksegese word aan die hoorders baie dinge (dikwels as waarskynlikhede) meegedeel wat nie in die teks staan nie. Die prediker laat hom nie in met modeme taalteorieë nie. En tog is die effek van psigologiese eksegese opvallend analoog aan die doel wat strukturaliste hulle stel, naanlik on die sogenaande dieptestruktuur van die teks na die oppervlakte te bring.

Schäfer toon aan dat predikante in Duitsland historiese feite in oordragtelike sin gebruik. Ons vind in bogenoemde preek dieselfde tendens. Die opsomming hierbo toon dit aan; óók die waarskuwing aan die jong hoorders: "pas op vir die kêrels van Sodom ... Pas op vir die dogters van Gomorra ..." (1990:12). Wanneer Sodom, sy 'poorte' en sy 'kêrels' oordragtelik gebruik word, word genoemde dinge van hulle historiese werklikheid afgesny en bloot simbole gemaak wat op die hoorders moet appelleer. Die probleem met hierdie eksegetiese metode is dat daar nie meer prinsipieel onderskeid gemaak kan word tussen party histoniese gegewens en ander nie. Om dit anders te sê: as Lot en Sodom in oordragtelike sin aangewend word met toespitsing op die hoorders, is daar slegs 'n klein stappie nodig om ook die kruis en Christus oordragtelik aan te wend, soos tans in Duitsland gebeur. Die glybaan van die allegorie het nie hindernisse nie.

'n Ander probleem van allegorisering is nie net om dinge in die Bybel in te lees wat nie daar staan nie maar ook om dinge wat wel in die teks staan, verby te 
gaan. So word die feit dat die engele na Lot gekom het toe hy "in die poort van Sodom" gesit het (Gen. 19:1), stilswyend in die preek verbygegaan. Dit pas eenvoudig nie in die betoogtrant van die preek nie. Stel jou voor: engele in die poort van Sodom! Dit kan tog nie. Engele in die hemel, ja, maar nie in die poort van Sodom nie. Die gedagte van engele, boodskappers van God is binne die raamwerk van hierdie preek ondenkbaar omdat Sodom reeds meer as een poort gekry het en 'die poorte van Sodom' allegories gefikseer is as simbool van onheil en sonde. Of, in terme van die preek: daar kan nie engele by slegte maats of by ' $n$ ongeoorloofde liefdesverhouding of in dobbelsale wees nie.

\subsubsection{Voorbeeld 4}

Ons vierde voorbeeld is nie ' $n$ preek nie maar ' $n$ skripsie, wat hier van belang is omdat daarin ook 'n bepaalde Skrifbeskouing en eksegetiese vertrekpunte aan die lig kom. Die studie van J. Kruger se titel is: 'n Eksegeties-diakoniologiese ondersoek na die belewing van skuld en skuldvergifnis in Psalm 32. Slegs enkele punte van belang word na vore gebring soos uit die studie blyk.

Vir Knuger lê die swaartepunt van Psalm 32 nie in die sonde van Dawid en sy gevolglike skuld nie, maar in die skuldbelewing van Dawid. Om daarby uit te kom word die Bybelse begrippe vir sonde, naamlik oortreding, sonde, ongeregtigheid (Ps. 32:1-2; vgl. vir die woordbetekenisse Davidson s.a., 635, 254, 590 resp.) as skuldbegrippe geëksegetiseer (Kruger, 1990:11-14). Die ontvangs van vergewing (vgl. Rom. 4:6-8) word ook verdring deur die belewing van skuldvergifnis. Hierdie psigologiese gesigspunt, wat met behulp van "eksegetiese afleidings" gemaak word (kyk Kruger, 1990:17, 20, 24), word dan riglyn vir die pastorale Woordbediening.

\subsubsection{Vir sosio-politieke doeleindes}

\subsubsection{Voorbeeld 1}

Skrifgegewens word soms oordragtelik gebruik om aan hoorders tuis te bring dat hulle sosiologiese en politieke situasie ' $n$ besondere gawe is wat waardeer en beskerm moet word. D'Assonville (s.a., 34-35) noem twee voorbeelde van sodanige preke. Omdat die klimaat dieselfde is, word albei hier saam behandel.

In 'n preek oor 2 Samuel 6:21 word gesê:

Soos God vir Israel 'n Ark gegee het, het Hy aan die Afrikanervolk gegee sy ver verlate vlaktes en sy ewige gebergtes ... Daarom kan ons vrolik wees voor die aangesig van die Here wat ons volk verkies het, net soos Hy Dawid verkies het. 
'n Radiopreek oor Nehemia 4:14 vertel aan die luisteraars hoe wonderlik die maand April is:

Nooit anders is herinnering vir die Afrikaner-Christen so opvallend teer, as die maand April nie. Want ver teen die agtergrond, aan die kim van die eeue, lê 'n graf en staan ' $n$ wieg. Die graf is die graf van ons Meester, en die wieg is die wieg van ons nasie. In April is ons Meester begrawe, en in April is ons nasie gebore. Afrikaner-Christenskap en Afrikanernasieskap is dew die Voorsienigheid van God op wonderbaarlike wyse verenig in die tydarms van dieselfde maand, April.

\subsubsection{Voorbeeld 2}

Die eerste twee sketse van Krusche in Calwer Predigthilfe is reeds onder die vorige punt behandel (kyk 2.1.1.1 en 2.1.1.2). Krusche se derde preekskets oor Johannes 19:16-30 het ten doel om die nood in die wêreld uit te wys en sy hoorders op sosiale en politieke gebied betrokke te laat raak.

Die derde voorbeeld van Krusche is immers 'n skets van 'betrokke' (aktuele) prediking, waarin die kritieke wêreldsituasie in ag geneem word. Teenoor Jesus se kruiswoord 'Dit is volbring', moet die prediker (soos Sölle ook doen - L.F.S.) die hoorders wys op alles wat in die wêreld nog 'nie volbring' is nie. Die 'wêreld in die teken van die kruis' is die visie op die geliefde wêreld van God. Dit stel 'kragte vry om die wêreld te verander, partyskap vir die lydendes en moed tot weerstand in die Naam van die Gekruisigde' te verkry (kyk Schăfer, 1993:92).

\subsubsection{Voorbeeld 3}

In 1986 het ' $n$ bundeltjie met die titel Kairos Liturgies verskyn. Dit bevat 'n paar preeksketse, relevante Skrifgedeeltes wat gelees kan word, gebede en psalms en gesange vir liturgiese gebruik.

Die eerste preekskets bevat nie 'n teks of perikoop wat verklaar word nie, maar in die loop van die uiteensetting word na verskeie tekste uit Lukas 23 en Johannes 19 as voorbeelde verwys. Die titel van die preek is: "Jesus was a victim of oppression" en die doel van die preek is: "To relate the suffering and death of Jesus to the experience of suffering and death under the oppression of apartheid" (Kairos Liturgies, 1986:4). In die "development" van die preek word onder andere gesê dat Jesus deur die polisie van sy tyd gearresteer is, dat Judas 'n informant was en dat die twee vals getuies "state witnesses" was.

Ten slotte word die hoofgedagte in die samevatting (conclusion) duidelik gestel: "Jesus was killed because in the name of God he sided with the poor and the oppressed and opposed their oppressors" (Kairos Liturgies, 1986:5). 
Die tweede preekskets word nie hier behandel nie, behalwe om na die samevatting te verwys: "He suffered in solidarity with us. We suffer in solidarity with him" (Kairos Liturgies, 1986:7).

' $n$ Mens kan nie anders as om die volgende raak te sien nie: as die Bybel 'n boek met voorbeelde word, en Jesus sélf ' $n$ voorbeeld word, word die kruis stereotiep verklaar as ' $n$ 'teken van solidariteit'. Ons tref hierdie verklaring in die eerste van Krusche se drie preeksketse aan en weer in die tweede preekskets in Kairos Liturgies. Nou mag die sielkundige, maatskaplike en politieke omstandighede van hoorders in Duitsland en in Suid-Afrika hemelsbreed verskil. Tog is Jesus in elke geval daar om die mens in sy nood te help. Wat Schäfer oor die drie preeksketse van Krusche opmerk, geld ook van die preeksketse van die Kairos Liturgies, naamlik dat die offergedagte na die agtergrond verskuif word. Na vore tree 'die Broeder', wat ons in sy krag, oorwinning, liefde en hoop meeneem. Schäfer (1993:93) stel dit só:

In den Predigtskizzen bleibt dieser Opfergedanke jedoch im Hintergrund. Nach vorne tritt "der Bruder", der uns in seine Würde, seine Kraft, seinen Sieg, sein Leben, seine Liebe und seine Hoffnung hineinnimmt.

\subsection{Herinterpretasie van die Skrif}

Hier word slegs een voorbeeld behandel - 'n voorbeeld waar die Skrif nie deur allegorie ' $n$ betekenisverandering ondergaan nie, maar direk geherinterpreteer word om ' $n$ vermeende hermeneutiese kloof te oorbrug. Die voorbeeld word weer uit Schäfer se artikel geneem.

Schäfer neem sy tweede voorbeeld uit die Göttinger Predigtmeditationen en bespreek die bydrae van Ernst Koch daarin (Schäfer, 1993:93-94). Ons het in Koch se bydrae myns insiens ' $n$ pragtige voorbeeld van die aksentverskuiwing van die teks na die hoorders. Koch stel immers 'n hermeneutiese probleem aan die orde, naamlik hoe die prediker ' $n$ 'koue teks' by sy hoorders met hulle konkrete nood en aanvegting moet laat posvat. Sy poging om die henneneutiese probleem op te los het allerlei eksegetiese en dogmatiese newe-effekte.

Maar kom ons keer terug tot Schäfer se weergawe om te sien hoe Koch die betrokke perikoop (Joh. 19:16-30) hanteer.

Koch begin sy bydrae met ' $n$ 'empiriese' berig. Hy het die betrokke perikoop aan 'n groep mense voorgelees om hulle reaksie daarop te kry. Die indruk van die groep was: die verhaal is verskriklik nugter, die teks laat ons koud en is weinig opbeurend.

Schăfer (1993:93) merk oor die reaksie van die groep op: 
Diese Urteile waren offenbar dadurch bedingt, dass in der Johannespassion anders als bei den Synoptikern kaum ein Spur von Anfechtung zu finden ist. (Hierdie oordele is duidelik daardeur bepaal dat in Johannes se weergawe van die lydensgeskiedenis, anders as by die sinoptici, kwalik 'n spoor van aanvegting te vind is - eie vertaling).

Die prediker staan gevolglik voor die homiletiese vraag: Waar staan die gelowige met sy onvermydelike stryd, sy aanvegting en smartlike ervaring dan? Hoe moet die teks na hom oorgebring word? As oplossing van die probleem stel Koch voor om Johannes se beeld van die lydende Jesus só te teken dat Hy reeds die lyding deurleef, verwerk en daardeur geryp is: Jesus "hat das Leiden so weit durchgestanden, das es sich 'in Auferstanden gewendet' hat" (Schäfer, 1993:93).

Vir die prediking bly die vraag egter knaag: wat help die grootliks onwerklike lyding van Jesus ons dan? Die 'toepassing' bring dié antwoord: ons moet óók begerig wees om lyding soos Jesus te kan deurstaan.

\section{Hoe het predikante vroeër gepreek?}

Die antwoord word teoreties gebied deur die vroeëre hermeneutiek en homiletiek, wat op 'n bepaalde Skrifbeskouing gegrond was. Hierdie Skrifbeskouing en sy implikasies vir die hermeneutiek en homiletiek was sedert die Reformasie deel van die Protestantse tradisie.

Daarom is in die gereformeerde homiletiek die nadruk nog altyd gelê op die inhoud van die Woord soos vervat in die teks of perikoop wat in die prediking uitgelê word. Prediking is verkondiging van die Woord van God. Calvyn sê (in Peter, 1971:L):

Waarom gee God aan ons die predikasies? Is dit nie om ons na Hom te trek nie? Dit is só asof Hy die hande na ons uitsteek, soos Jesaja sê. Ook word die prediking van die evangelie nie sonder rede ' $n$ visitasie van God genoem nie (eie vertaling).

Eksegese is vir Calvyn die wagwoord. Hy dring aan op woord-vir-woord-eksegese van die teks/perikoop, terwyl tersaaklike Skrifgedeeltes wat die teks kan belig, betrek moet word (Peter, 1971:L).

In terme van die huidige kommunikasieleer lê die volle aksent vir Calvyn op die Sender en sy boodskap. Die gereformeerde homiletiek het Calvyn se siening van die prediking gevolg.

Die visie op die prediking as verkondiging van die Woord van God was nie die gevolg van 'n formele Skrifbeskouing nie - dit was die resultaat van die herontdekking van die lewende en kragtige inhoud van die Woord. 
Gevolglik was die Hervormers diep bewus daarvan dat die prediking die lewende stem van God is, magtig om sondaars te bereik en te vernuut. Daarvan getuig Zwingli $(1940,3: 58)$ op treffende wyse:

Hier kan ek inderdaad van mense praat, wie se name ek verkies om nie te noem nie, wat uitnemend vorder - ewige lof en dank aan God! - in liefde tot God, in vrede met hulle naaste, in die kennis van die evangelie, in eenvoud van lewe, in godsalige kennis, in die gee van aalmoese en hulp aan die armes, in afbraak van hulle hoogmoed, in vergewing van hulle vyande, in belangstelling vir die leer van Christus ... (eie vertaling).

Hierdie transformerende krag van die evangelie in menselewens én samelewing veronderstel die verdorwenheid van die mens, genadeloos oopgevlek deur die wet, en die genadevolle vryspraak van die skuld deur die versoeningswerk van Christus. Die regverdige God, wat in sy wet verdoem, is dieselfde God wat in sy barmhartigheid ons vervloeking op sy Seun laai en ons vryspreek. Daarom was skuld en vryspraak, boete en geloof, nederigheid en lofsegging lewenswerklikhede vir die Protestant van die l6de eeu. Die vrees van God was voor sy oë (vgl. Peter, 1984:26-30).

Nogeens: die Hervormers het alles van die lewende en werkende Woord van God verwag. Die vernuwing van mens en maatskappy was die gevolg van die werk van die lewende God deur sy Woord en Gees.

Wanneer die Protestantse teologie dus nog tot aan die begin van die jare sewentig die aksent op die Bybelteks plaas, is dit nie gedoen om allerlei teoretiese redes nie maar uit die diep geloofsoortuiging dat God deur sy Woord alles doen wat Hom behaag.

\section{Die pad vorentoe}

\subsection{Situasie-analise}

Die vorige punt (pt. 3) as agtergrond gee ons 'n kykie in die diepte en omvang van die sogenaamde paradigmaverskuiwing in die moderne homiletiek. Dit is inderdaad ' $n$ verskuiwing van vertrekpunte - nie maar van bloot 'teoreties-wetenskaplike' vertrekpunte nie maar van geloofsvertrekpunte. Soos daar agter die 'verouderde' homiletiek 'n bepaalde opvatting van God, sy Woord en die mens gelê het, lê daar agter die moderne homiletiek 'n ander opvatting van God, die Bybel en die mens. God (as Hy nie afwesig is nie) word minder belangrik en die mens, mondig verklaar deur die Verligting, word meer belangrik. God (resp. Christus) word die Helper van die mens in sy sielkundige, sosiale en politieke nood. Daarmee saam verander die rol van die predikant ook. 
Vertrek die prediker van die soewereine God en sy Woord, is hy slegs dienaar wat die uitgestrekte hande van God om sondaars te red en te versterk, sigbaar maak. Vertrek die prediker van die mens (die ontvanger of hoorder), word hy die agent om die mens in sy nood by te staan. Prediking is gevolglik nie meer verkondiging van die gesagvolle en werkende Woord van God nie maar intermenslike kommunikasie. Die lewensbeskoulike verandering wat agter die moderne homiletiek lê, bepaal die prediker se siening van wie God is, wat die Bybel is en wat die mens is.

In dié proses verander die rol van die Bybel ook. Omdat die Sender na die agtergrond verskuif word, word die boodskap ook sekondêr. Gevolglik word die Bybel instrument in die hande van die prediker wat deur allegorie, eksegetiese afleidings of herinterpretasie só uitgelê word dat dit die hoorders in hulle nood moet rigting gee.

Die lot wat die Bybel tref, is ook die lot van die ander 'genademiddels', naamlik die sakramente. Die doop word (goed Wederdopers) gesien as die toetrede van die mens tot die kerk, en in die Nagmaal lê die aksent op die gemeenskap, eerder as op die verseêling van die vergewing van sondes. Schäfer (1993:96) beskryf die Nagmaalsviering in die lig van die moderne prediking met die volgende woorde:

das Abendmahl (ist) weniger Vergebung der Sünde als vielmehr Feier der Gemeinschaft.

Natuurlik is die Woord (soos die sakramente) instrument - maar nie instrument in die hand van die prediker om daarmee 'bal te speel' nie (vgl. Calvyn, 1979:175 komm. 2 Kor. 3:6) maar instrument in die hand van God, wat deur sy Gees sy verlossingswerk volbring.

Eén saak is duidelik: in al bogenoemde voorbeelde word die Skrif ter wille van die hoorders aangewend om dinge te sê wat nie geskryf staan nie en om dikwels dit wat wel geskryf staan, te ignoreer. Die aksentverskuiwing van die Bybelteks na die hoorder(s) verraai 'n verstommende disrespek vir die Woord van God en vir die God van die Woord - iets wat vreemd is aan die gereformeerde teologie.

\subsection{Riglyn}

Die huidige gereformeerde homiletiek sal deurdronge moet bly van die gesag en volkomenheid van die Woord van God, soos ons dit bely in artikels 3-7 van die NGB. Dit geld óók van die hermeneutiek 


\subsubsection{Implikasies (negatief)}

- Bogenoemde uitgangspunt impliseer dat daar ten alle koste gewaak sal word om, op grond van die veelgeroemde 'wetenskaplikheid' van die teologie, ' $n$ kloof tussen geloof (konfessie) en wetenskap te skep. Die gevolg van so 'n kloof is dat die homiletiek haaks op die geloof van die kerk staan, soos uit bogenoemde Duitse preekbundels blyk, en - wat erger is - die Skrifopenbaring geweld aandoen.

* Dit hou tweedens in dat die gereformeerde teologie (i.c. homiletiek en hermeneutiek) die moderne aksentverskuiwing van die teks na die hoorder sal weerstaan omdat dit kragtens sy aard primêr aan die teks gebind is. Op so 'n wyse sal die saak (Woord) steeds aan die orde kom en sal die gereformeerde teologie nie in byna patologiese selfrefleksie bly vassteek in teoretiese en metodologiese voorvrae nie (vgl. De Villiers, 1991:145).

- Die eie aard van die Skrif as positiewe gegewe moet konsekwent vasgehou word - ook die eie aard van sy verhalende dele. Dit is immers historiese verhale van God se handelinge met individue en met sy volk. Wanneer taalteorieë (strukturalisme, resepsieteorie) argeloos op die Skrif toegepas word, word die eie aard van die Skrif misken. Taalteorieë is immers gebaseer op gewone literatuur. So byvoorbeeld is Greimas se narratiewe eksegese en metode van analise gebou op Vladimir Propp se bestudering van 'n versameling van 100 Russiese sprokies (Cloete et al., 1985:46). Wanneer hierdie aktansiële analise op die Bybel toegepas word, is die veronderstelling dat alle verhale (fiktiewe sprokiesverhale en historiese Bybelverhale) dieselfde struktuur en betekenis het. Sodoende word die eie aard van die Skrif en die verskeidenheid van gegewens in die skepping misken. Stoker (1940:302) merk oor die beperkte geskiktheid van 'n metode die volgende op:

Hierdie geskiktheid eis juis, dat dit aan die gegewens van ondersoek aangepas moet wees, niks daaraan mag toe- of afdoen nie, d.w.s. niks daaraan mag verander nie. Omdat die gegewens waarlik verskil, het verskillende metodes ook ' $n$ beperkte gebied, waar hulle bruikbaar is; introspeksie is in skeikunde onbruikbaar en eksperiment is in Bybeleksegese sinloos.

- Die uitgangspunt soos gestel in 5.2, sal die gereformeerde teologie ten slotte daarvan bewaar om in die gebruik van metodes en teorieë van ander vakwetenskappe (bv. literatuurwetenskap, antropologie en sosiologie) die beperkte aard en geskiktheid daarvan te vergeet en deur die metodes en teorieë op sleeptou geneem te word. Die klakkelose navolging van sodanige teorieë en metodes kan slegs lei tot ' $\mathrm{n}$ horisontale antroposentrisme (kyk voorbeelde hierbo) of tot 'n heillose relativering van die teks in 'n sogenaamde postmodemistiese sin (De Villiers, 1991:148; kyk ook Nethersole, 1982:151152; Cooper, 1993:109-113). 


\subsubsection{Positiewe implikasies}

* Jesus het nie die koninkryk van die mens verkondig nie, ook nie die koninkryk van die kerk nie, maar die koninkryk van God. God openbaar Hom in sy Woord as die lewende, almagtige Koning oor sy skepping. In sy almagtige koningsheerskappy verlos hy die gevalle skepping. Daarom het Christus nie net soteriologiese betekenis nie maar kosmiese betekenis (Kol. 1:15-20). Markus lig aan die begin van sy evangelie vir 'n oomblik die sluier wat ons 'n kykie gee in die kosmiese oorwinningswerk van Christus: Nadat $\mathrm{Hy}$ die duiwel in die woestyn verslaan het, triomfeer $\mathrm{Hy}$ as Paradyskoning en word iets van die vrede van die herstelde skepping sigbaar ... " en Hy was saam met die wilde diere en die engele het Hom gedien" (Mark. $1: 13(b)$ ). Ondertussen het geen mens dit gesien nie, die enigste getuies van die nuwe vrede is ander skepsels: engele ... en diere!

* Die perspektief op die koninkryk sal die gereformeerde teologie bewaar van 'n soteriologiese versmalling en 'n antroposentriese reduksie van die evangelie. Dan sal die Bybel nie vermink word tot 'n eksemplariese moraalboek nie en die mens as 'bondgenoot' nie opgejaag word tot 'n deurslaggewende faktor wat lei tot 'n kondisionele regverdigmaking nie. Die soewereine God sal in die oog bly en die krag van sy transformerende Woord sal verkondig word.

\section{Bibliografie}

ANON 1974 Kommunikasie In Ensiklopedie van die wêreld, 6:177-178.

BARTH, K 1966 Homiletik Zürich : EVZ

BERNSTEIN, R J. 1983 Beyond Objectivism and Relativism Oxford : Blackwell

BOHREN, RUDOLPH. 1974 Predigtlehre $3^{\mathrm{e}}$ Af München : Kaiser.

CALVYN, J 1979. Commentary on the Epistles of Paul to the Corinthians, vol 2 Trans. by J. Pringle Repr. Grand Rapids : Baker.

CLOETE, T T, BOTHA, E, MALAN, C reds. 1985 . Gids by die Literatuurstudie Pretoria : HAUM

COOPER, J W. 1993 Reformed Apologetics and the Challenge of Postmodern Relativism Calvin Theological Journal, 28(1):108-120.

D'ASSONVILLE, VE s.a Kerk en prediking (Die stryd om die kerk, nr. 5) Potchefstroom : Die Evangelis

DAVIDSON, B s a (1943?) The Analytical Hebrew and Chaldee Lexicon London Bagster and sons

DE VILLIERS, P GR 1991 The End of Hermeneutics? On New Testament Studies and Postmodernism. Neotestamentica, 25(1) 145-156.

DIJK, K. 1955. De dienst der prediking Kampen Kok.

DINGEMANS, GD J 1992 Ontwikkelingen in de homiletiek: Een overzicht van recente literatuur Nederlands Theologisch Tijdschrift, 46(2):124-131, April

GREIDANUS, S 1970 Sola Scriptura Toronto: Wedge

GREIDANUS, S 1989 The Modern Preacher and the Ancient Text Repr Grand Rapids

Eerdmans 
ISER, WOLFGANG. 1970 Die Appelstruktuur der Texte: Unbestimmtheit als Wirkungsbedingung literarischer Prosa. Konstanz: Universitätsverlag.

JAUSS, HR. 1970. Literaturgeschichte als Provokation. Frankfurt : Suhrkamp

KAIROS LITURGIES, 1986. Braamfontein : Southern Transvaal Kairos Liturgy Group.

KROMMINGA, C.G. 1983. Remember Lot's Wife: Preaching Old Testament Narrative Texts. Calvin Theological Journal, 18(1):32-46

KRUGER, J. 1990. 'n Eksegeties-diakoniologiese ondersoek na die belewing van skuld en skuldvergifnis in Psalm 32. (Th.B -skripsie, PU vir CHO.)

MALAN, C.J. 1990 Net een ding is nodig Potchefstroom: Geref. Kerk Noordbrug

McCARTHY, T. 1982. Rationality and Relativism: Habermas's 'overcoming' of Hermeneutics. (In Thompson, J.B. \& Held, D., eds Habermas. Critical Debates. London : MacMillan. p. 57-78.)

NETHERSOLE, R. 1982. Literary Hermeneutics: A Theory for Understanding Texts (In Ryan, R. \& Van Zyl, S., eds An Introduction to Contemporary Literary Theory. Johannesburg : Donker. p 147-160.)

PETER, R. 1971. Introduction: l'homiletique de Calvin (In Jean Calvin, Sermons sur les livres de Jérémie et des Lamentations, publiés par Rodolphe Peter (Supplementa Calviniana, vol. 6). Neukirchen-Vluyn : Neukirchener Verlag des Erziehungsvereins p. XIIX-LVII.)

PETER, R. 1984 Genève dans la prédication de Calvin (In Neuser, W. H, red. Calvinus ecclesiae genevensis custos. Frankfurt a $\mathrm{M}$ : Lang. p. 23-48.)

PIETERSE, H J.C. Ongepubliseerd Praktiese Teologie as kommunikatiewe handelingsteorie (eerste ms. in 'n reeks studies in Praktiese Teologie, wat binnekon gaan verskyn).

PIETERSE, H J C. 1985. Verwoording en prediking. Pretoria : N G. Kerkboekhandel

PIETERSE, H.J.C. 1987. Communicative Preaching Pretoria : Unisa

ROUTLEY, E. 1950. The Church and Music London : Duckworth

SCHÄFER, R. 1993. Erfahrungsbericht: Theologie des Kreuzes in Gottesdienst und Predigt Kerugma und Dogma, 39(2) 90-99, April/Juni

STOKER, H.G 1940. Beginsels van 'n Christelike wetenskapsleer ( $/$ K Koers in die krisis 2 Stellenbosch : Pro Ecclesia. p 293-331.)

STRYDOM, M C. 1989. Eksemplaries ... Heilshistories. Voorsetting van 'n onvoltooide gesprek Bloemfontein: VCHO.

TRILHAAS, WOLFGANG. 1948. Evangelische Predigtlehre $3^{\mathrm{e}}$ Afl Munchen : Kaiser

ZWINGLI, H. 1940. Hauptschriften Bearb von F Blanke, O Farner, R Pfister Bd 3. Zürich : Zwingli-Verlag. 